\title{
Comparison of parenting styles and mental health among students
}

\author{
Soraya Nasrollahzade ${ }^{1, *}$, Hemn Mahmoudfakhe ${ }^{2}$, Aref Rahmani ${ }^{3}$ \\ ${ }^{1}$ Department of Psychology, Payame Noor University, PO BOX 19395 - 3697, Tehran, IRAN \\ ${ }^{2}$ Department of Psychology, Payame Noor University, PO BOX 19395 - 3697, Tehran, IRAN \\ ${ }^{3}$ Department of Clinical Psychology, Rudehen Branch, Islamic Azad University, Rudehen, IRAN \\ E-mail address: soshyakhan@gmail.com
}

\begin{abstract}
Keywords: Parenting styles, Mental health, Permissive styles, Authoritative styles and Tolerant styles.
\end{abstract}

\begin{abstract}
The aim of the present research was to compare parenting styles and mental health among students. The statistical population of the paper included all the female and male third grade high school students in the city of Boukan. The sample was selected through simple random style in access which included 340 people of both sexes. The tools used in this research comprises two: Baumrind parenting style and Goldberg's general health questionnaires. Findings revealed that this research is of a causal-comparative nature and it was established that there was a difference between mental health of the two sexes; there was also a difference between the two sexes.
\end{abstract}

\section{INTRODUCTION}

Family is the first founder of the attributes and values as well as thinking standards of the child and plays an ever increasing role in establishing his fate and life style in the future. The child's reaction to his own environment will be naturally affected by the group's social and cultural relations in which he has grown up. Since, the family is a social unit and through which values and social standards are transferred to the child, its intermediacy rile assumes prominent importance in terms of the social environment effects (Ahmadvand, 2003).

Family is one of the most fundamental social institutions and is thought to be the cradle of nurture for the child during his primary growing stages. For this, any disruption with the family could leave harmful impacts on the child (Ahadi et al, 1993). The way parents establish communications with the children is thought of the strongest effective factor on familial interactions, particularly, in stages of life when children go through fundamental developments of mental growth. Researches surrounding children's mental ills illustrate that most families are in disagreements over unfavorable parenting styles which are deemed to be origins of fear, mistrust, sense of dissatisfaction, pessimism and anxiety in children; however, they apply parenting styles based on rejection, extreme support along with negligence or dominance, dual discipline, loose moral relations, irrational perfectionism and emotional rage and instability.

Families apply different parenting styles while rearing their own children. Parenting styles involve relatively stable means and paradigms by parents for communicating with their members of the family, thus allowing for reciprocal influence. Parenting styles could be divided into three categories: permissive parenting style, authoritative parenting style and rational authority style. The family function wherein rational authority is applied is stronger. Families which follow the principle of collaboration and democracy in relations in rearing their children and are assumed to be enjoying more abilities for adapting to changes will allow conducive conditions for their children (Berk, 2001). Mental health has been defined as some relatively good adaptation state, feeling of wellbeing and actualization of personality capacity and talents. This term is usually applied for people who act at a higher level of emotional and behavioral adaptation not those who are not simply ill. On the other hand, the mental health science is a branch of Health which is concerned with prevention of mental disorder and maintenance of optimum life styles as well as emotional health. The mental health science is a permanent process which continues from birth to death. Man needs to be nurtured and that is necessary for mankind; the one who is not nurtured well not only will 
waste his life but also, he will leave immense impacts on people socially. Child is like herb which needs various things for its growth; if the herb is not fed and receives no air, it will corrupt. Tyrants and criminals are all born out of false education and nurturing whereas the pious and true servants of the community have reached such high positions out of clear and proper nurturing. Thus, there will be no nurturing without civilization. Nurturing thus assumes higher importance and leaves personal and social impacts; individually speaking, it involves material and spiritual growth while socially speaking, it will consist of advancement, security and group comfort. It is better for man to be in the show of a child and perceives his society as loose and corrupt so that he understands its importance (Ghaemi, 2003). Child experts and psychologists consider the cause of most children abnormalities as the familial relations and parents; child rearing styles and hence they emphasize on the impacts of events and childhood era on formation of peoples' personality and their future life. In regard to the fact that mental conditions will undoubtedly not change without changing in the function of the families, thus children's behaviors and their interaction with the other members of the family need to be considered. In this research, we are going to be discussing the fact that what sort of relation exists between parenting styles and mental health and we will be addressing the issue that whether educational methods and styles will have impacts on the mental health of the children or not.

\section{RESEARCH OBJECTIVES}

Overall research objectives:

Establishment of relation of parenting styles and mental health among third grade high school students

Secondary objectives:

Establishment of difference of female and male students' mentalhealth

Establishment of relation of parenting styles and mental healthamong male and female students

Establishment of relation of parenting styles and mental healthcomponents among students

Research hypotheses:

There is a difference in mental health $\mathrm{f}$ the two sexes

There is a difference between parentingstyles of the two sexes

\section{METHODOLOGY}

The statistical population of the paper included all the female and male third grade high school students in the city of Boukan in the educational year of 2014-2015. The sample was selected through simple random style in access which included 340 people of both sexes based on a Morgan table. The tools used in this research comprises two Baumrind parenting style and two Goldberg's general health questionnaires. The methodology of this research is of a causal-comparative nature.

Baumrind parenting styles:

This questionnaire has been quoted from the parents' authority and developed on the basis of Baumrind investigation in relation with the parenting styles. This questionnaire consists of 30 statements where 10 of which concern permissive styles, the other 10 concern authoritative style while the remaining 10 statements are related with tolerant parenting styles.

Validity and reliability of the parenting styles

In 1991, Burry reported the reliability of this questionnaire by using the retest method among mothers as the following: 
$0 / 81$ for the permissive style, $0 / 86$ for the authoritative style, $0 / 78$ for the decisive and reassuring style. Also, the reliability of the questionnaire among fathers: $0 / 77$ for the permissive styles, $0 / 85$ for the authoritative style and 0/92 for the rational authority.

He further used the differential method for investigating the questionnaire validity and observed that the authorization of mothers is found to be reversely related with permissive styles $(-0 / 38)$, mother's rational authority (-0/48). Also, father's authorization has a reverse relationship with permissiveness $(-0 / 50)$ and his authority $(0 / 52)$.

Goldberg's general health test

The general health test was developed by Goldberg in 1972. The 28 question form consists of four 7 question scales (physical signs, anxiety, social dysfunction and depression).

Validity and reliability if the Goldberg's General Health Test:

Goldberg and Blackwell (1970) have stated the validity of the questionnaire by using a checklist of clinical interview on the surgical ward at 0/80. In another study, Goldberg et al (1976) stated the correlation of the said questionnaire along with a 90 symptom list revised by Dragotis et al (1976) at 0/78 ( Houman, 1999). Meta-analysis of 30 researches conducted by Williams and Marry (1988) indicated that the average sensitivity (proportion of proper diagnosis of the patients by suing the clinical interview) as $0 / 84$ and the average of attribute (proportion of proper diagnosis of healthy people from the patient people by using clinical interview) at $0 / 82$.

In a study, Yaghobi (2001) reported the sensitivity and attribute of this questionnaire at the best cutoff point (score 23) as 0/86.5 and \%82 respectively. In the research by Houman (2003), the sensitivity and attribute of the questionnaire were reported to be $83 / 3$ and $\% 76$. Also, its correlation degree along with a 90 sign list (where Dragotis et al reported the rate of 0/82) suggests some considerable validity of the test. In an investigation by Chung and Spears (1994) in New Zealand, the reliability coefficient in retest form was obtained $0 / 55$ with a time interval of 2-4 weeks. In another study conducted by Chun in 1983, the internal constancy coefficient along with the Cronbach's alpha was obtained to be $0 / 85$ (Houman, 2003). In the research by Yaghobi (2001) the questionnaire reliability coefficient was 0/88 through retest method. Also, in the Houman investigation (2003) the internal constancy coefficient was reported to be 0/83 (Houman, 2003).

\section{DATA ANALYSIS METHODS}

In this research, the SPSS software method was applied for analyzing data. Descriptive statistics (tables and graphs) and inferential statistics were applied for expressing differences and the t-test was used for the relationship between hypotheses as well as Pearson correlation.

Hypothesis 1 and 2: given the fact that the scale is distance-based the t-test is used

Hypothesis 3: Given the fact that the scale is distance-based, the Pearson correlation coefficient is used

Hypotheses 4-15: the t-test is used for investigating the difference between the variables. 


\section{FINDINGS}

Hypothesis 1: There is a difference between the two sexes in terms of mental health

Table 1. T-test and variance homogeneity are illustrated for the mental health in terms of sexes

\begin{tabular}{|l|l|l|l|l|l|}
\hline Variable & $\begin{array}{l}\text { F variance } \\
\text { homogeneity }\end{array}$ & F significance & T quantity & $\begin{array}{l}\text { Freedom } \\
\text { degree }\end{array}$ & T significance \\
\hline $\begin{array}{l}\text { Male } \\
\text { mental } \\
\text { health }\end{array}$ & $1 / 69$ & $0 / 255$ & $2 / 04$ & 168 & $0 / 01$ \\
\hline $\begin{array}{l}\text { Female } \\
\text { mental } \\
\text { health }\end{array}$ & $0 / 689$ & $0 / 940$ & $5 / 45$ & 168 & $0 / 01$ \\
\hline
\end{tabular}

The results obtained indicate that the average mental health is different between the two sexes. This average is 29/54 for men and 39/37 for women. Therefore, the significance level obtained ( $\mathrm{sig}=0 / 94$ ) illustrates that the significance of the above test is less than $\% 1$. Thus, the hypothesis is rejected and the main hypothesis is supported. In other words, there is a significant difference between the two variables mentioned.

Hypothesis 2: There is a difference in the two sexes in terms of parenting styles

Table 2. T- test and variance homogeneity are shown for the parenting styles in terms of sex

\begin{tabular}{|l|l|l|l|l|l|}
\hline Variable & $\begin{array}{l}\mathrm{F} \text { variance } \\
\text { homogeneity }\end{array}$ & $\begin{array}{l}\mathrm{F} \\
\text { significance }\end{array}$ & T quantity & $\begin{array}{l}\text { Freedom } \\
\text { degree }\end{array}$ & $\begin{array}{l}\mathrm{T} \\
\text { significance }\end{array}$ \\
\hline $\begin{array}{l}\text { Male } \\
\text { mental } \\
\text { health }\end{array}$ & $1 / 898$ & $0 / 003$ & $7 / 59$ & 168 & $\% 5$ \\
\hline $\begin{array}{l}\text { Female } \\
\text { patenting } \\
\text { health }\end{array}$ & $2 / 561$ & $0 / 00$ & $7 / 43$ & 168 & $\% 5$ \\
\hline
\end{tabular}

The results obtained indicate that the average mental health is different between the two sexes. This average is 73/09 for men and 68/48 for women. Therefore, the significance level obtained ( $\mathrm{sig}=0 / 003$ ) illustrates that the significance of the above test is less than $\% 5$. Thus, the hypothesis is rejected and the main hypothesis is supported. In other words, there is a significant difference between the two variables mentioned.

Hypothesis 3: There is a relationship between parenting styles and mental health

Table 3. Shows the correlation coefficient between parenting styles and mental health of the sample people

\begin{tabular}{|l|l|l|l|l|}
\hline Variables & $\mathrm{N}$ & $\begin{array}{l}\mathrm{R} \text { correlation } \\
\text { coefficient }\end{array}$ & $\begin{array}{l}\text { 2.tailed } \\
\text { significance }\end{array}$ & $\begin{array}{l}\text { Freedom } \\
\text { degree } \\
\text { (DF) }\end{array}$ \\
\hline Parenting style & 340 & $0 / 301$ & $\% 1$ & 338 \\
\hline Mental health & 340 & & 338 \\
\hline
\end{tabular}

The R Pearson test was applied for testing the relationship and correlation between parenting and mental health of the sample people where the results suggested there is a significant relationship between the two variables with the significance level of $0 / 01$. We have the intensity of correlation as $\mathrm{R}=0 / 301$. This means that as type of parenting changes, so will mental health of the people. 
Hypothesis 4: there is a difference between the average parenting scores (permissive) on the depression scale with the average parenting (authoritative).

Table 4. Indicates the t-test and variance homogeneity for the depression level and parenting styles

\begin{tabular}{|l|l|l|l|l|l|}
\hline Variable & $\begin{array}{l}\text { F variance } \\
\text { homogeneity }\end{array}$ & F significance & T quantity & $\begin{array}{l}\text { Freedom } \\
\text { degree }\end{array}$ & $\begin{array}{l}\text { T } \\
\text { significance }\end{array}$ \\
\hline $\begin{array}{l}\text { Male mental } \\
\text { health }\end{array}$ & $1 / 119$ & $0 / 365$ & $1 / 56$ & 64 & $\% 1$ \\
\hline $\begin{array}{l}\text { Female } \\
\text { patenting } \\
\text { health }\end{array}$ & $0 / 761$ & $1 / 704$ & $1 / 94$ & 122 & $\% 1$ \\
\hline
\end{tabular}

Results obtained indicate that the average depression is different in two patenting styles (permissive and authoritative). This average is $8 / 36$ for the permissive style and $7 / 89$ for the authoritative style where this difference is significant. Therefore, the significance level obtained (sig=0/339) illustrates that the significance of the above test is less than $\% 1$. Thus, the hypothesis is rejected and the main hypothesis is supported. In other words, there is a significant difference between the two variables mentioned.

Table 5. There is a difference between parenting scores average (permissive) on the anxiety scale with average parenting styles (authoritative)

\begin{tabular}{|l|l|l|l|l|l|}
\hline Variable & $\begin{array}{l}\text { F variance } \\
\text { homogeneity }\end{array}$ & $\begin{array}{l}\mathrm{F} \\
\text { significance }\end{array}$ & T quantity & $\begin{array}{l}\text { Freedom } \\
\text { degree }\end{array}$ & $\begin{array}{l}\text { T } \\
\text { significance }\end{array}$ \\
\hline $\begin{array}{l}\text { Anxiety of } \\
\text { permissive } \\
\text { style }\end{array}$ & $0 / 804$ & $0 / 691$ & $1 / 96$ & 63 & $\% 1$ \\
\hline $\begin{array}{l}\text { Anxiety of } \\
\text { authoritative } \\
\text { style }\end{array}$ & $1 / 073$ & $0 / 405$ & $2 / 32$ & 119 & $\% 1$ \\
\hline
\end{tabular}

Results obtained indicate that the average anxiety is different in two patenting styles (permissive and authoritative). This average is $10 / 32$ for the permissive style and 11/57 for the authoritative style where this difference is significant. Therefore, the significance level obtained $(\mathrm{sig}=0 / 286)$ illustrates that the significance of the above test is less than \%1. Thus, the hypothesis is rejected and the main hypothesis is supported. In other words, there is a significant difference between the two variables mentioned.

Hypothesis 6: There is a difference between parenting style (permissive) on the scale of physical signs and parenting style average (authoritative)

Table 6. Indicates t-test and homogeneity on the scale of physical signs and average of parenting style (authoritative)

\begin{tabular}{|l|l|l|l|l|l|}
\hline Variable & $\begin{array}{l}\text { F variance } \\
\text { homogeneity }\end{array}$ & $\begin{array}{l}\mathrm{F} \\
\text { significance }\end{array}$ & T quantity & $\begin{array}{l}\text { Freedom } \\
\text { degree }\end{array}$ & $\begin{array}{l}\text { T } \\
\text { significance }\end{array}$ \\
\hline $\begin{array}{l}\text { Permissive } \\
\text { style physical } \\
\text { problems }\end{array}$ & $0 / 996$ & $0 / 271$ & $1 / 52$ & 62 & $\% 1$ \\
\hline $\begin{array}{l}\text { Authoritative } \\
\text { style physical } \\
\text { problems }\end{array}$ & $0 / 748$ & $0 / 739$ & $1 / 52$ & 120 & $\% 1$ \\
\hline
\end{tabular}


Results obtained indicate that the average physical sign is different in two patenting styles (permissive and authoritative). This average is $8 / 09$ for the permissive style and $8 / 75$ for the authoritative style where this difference is significant. Therefore, the significance level obtained ( $\mathrm{sig}=0 / 248$ ) illustrates that the significance of the above test is less than $\% 1$. Thus, the hypothesis is rejected and the main hypothesis is supported. In other words, there is a significant difference between the two variables mentioned.

Hypothesis 7: There is a difference between the average parenting style scores (permissive) on the social dysfunction scale and average parenting average (authoritative)

Table 7. Indicates t-test and homogeneity of variances for the social dysfunction for the two patenting styles

\begin{tabular}{|l|l|l|l|l|l|}
\hline Variable & $\begin{array}{l}\text { F variance } \\
\text { homogeneity }\end{array}$ & F significance & T quantity & $\begin{array}{l}\text { Freedom } \\
\text { degree }\end{array}$ & $\begin{array}{l}\text { T } \\
\text { significance }\end{array}$ \\
\hline $\begin{array}{l}\text { Social } \\
\text { dysfunction } \\
\text { in the } \\
\text { permissive } \\
\text { style }\end{array}$ & $1 / 043$ & $0 / 436$ & $1 / 85$ & 61 & $\% 1$ \\
\hline $\begin{array}{l}\text { Social } \\
\text { dysfunction } \\
\text { in } \\
\text { authoritative } \\
\text { style }\end{array}$ & $0 / 615$ & $0 / 868$ & $1 / 62$ & 121 & $\% 1$ \\
\hline
\end{tabular}

Results obtained indicate that the average social dysfunction is different in two patenting styles (permissive and authoritative). This average is 13/33 for the permissive style and 10/29 for the authoritative style where this difference is significant. Therefore, the significance level obtained ( $\mathrm{sig}=0 / 432$ ) illustrates that the significance of the above test is less than $\% 1$. Thus, the hypothesis is rejected and the main hypothesis is supported. In other words, there is a significant difference between the two variables mentioned.

Hypothesis 8: There is a difference between the average parenting style (tolerant) on the depression scale and average parenting style (authoritative)

Table 8. Indicates t-test and homogeneity of variances for the depression level in two parenting styles

\begin{tabular}{|l|l|l|l|l|l|}
\hline Variable & $\begin{array}{l}\mathrm{F} \text { variance } \\
\text { homogeneity }\end{array}$ & $\begin{array}{l}\mathrm{F} \\
\text { significance }\end{array}$ & T quantity & $\begin{array}{l}\text { Freedom } \\
\text { degree }\end{array}$ & $\begin{array}{l}\mathrm{T} \\
\text { significance }\end{array}$ \\
\hline $\begin{array}{l}\text { Tolerant } \\
\text { style } \\
\text { depression }\end{array}$ & $0 / 553$ & $0 / 930$ & $1 / 77$ & 148 & $\% 1$ \\
\hline $\begin{array}{l}\text { Authoritative } \\
\text { style } \\
\text { depression }\end{array}$ & $1 / 242$ & $0 / 252$ & $1 / 94$ & 122 & $\% 1$ \\
\hline
\end{tabular}

Results obtained indicate that the average depression is different in two patenting styles (tolerant and authoritative). This average is $5 / 55$ for the permissive style and $7 / 89$ for the authoritative style where this difference is significant. Therefore, the significance level obtained (sig=0/678) illustrates that the significance of the above test is less than $\% 1$. Thus, the hypothesis is rejected and the main hypothesis is supported. In other words, there is a significant difference between the two variables mentioned. 
Hypothesis 9: There is a difference between the average parenting style scores (tolerant) on the scale of anxiety with average parenting style (authoritative)

Table 9. Indicates t-test and homogeneity of variances for the level of anxiety in two parenting styles

\begin{tabular}{|l|l|l|l|l|l|}
\hline Variable & $\begin{array}{l}\mathrm{F} \text { variance } \\
\text { homogeneity }\end{array}$ & $\begin{array}{l}\mathrm{F} \\
\text { significance }\end{array}$ & T quantity & $\begin{array}{l}\text { Freedom } \\
\text { degree }\end{array}$ & $\begin{array}{l}\mathrm{T} \\
\text { significance }\end{array}$ \\
\hline $\begin{array}{l}\text { Tolerant } \\
\text { style anxiety }\end{array}$ & $1 / 054$ & $0 / 409$ & $2 / 14$ & 152 & $\% 1$ \\
\hline $\begin{array}{l}\text { Authoritative } \\
\text { style anxiety }\end{array}$ & $0 / 807$ & $0 / 681$ & $2 / 32$ & 119 & $\% 1$ \\
\hline
\end{tabular}

Results obtained indicate that the average anxiety is different in two patenting styles (tolerant and authoritative). This average is $6 / 82$ for the tolerant style and $11 / 57$ for the authoritative style where this difference is significant. Therefore, the significance level obtained ( $\mathrm{sig}=0 / 272)$ illustrates that the significance of the above test is less than $\% 1$. Thus, the hypothesis is rejected and the main hypothesis is supported. In other words, there is a significant difference between the two variables mentioned.

Hypothesis 10: There is a difference between the average parenting style scores (tolerant) on the physical problems scale with average parenting style (authoritative)

Table 10. Indicates t-test and homogeneity of variances for the level of anxiety in two parenting styles

\begin{tabular}{|l|l|l|l|l|l|}
\hline Variable & $\begin{array}{l}\text { F variance } \\
\text { homogeneity }\end{array}$ & F significance & T quantity & $\begin{array}{l}\text { Freedom } \\
\text { degree }\end{array}$ & T significance \\
\hline $\begin{array}{l}\text { Tolerant style } \\
\text { physical signs }\end{array}$ & $1 / 135$ & $0 / 334$ & $2 / 06$ & 152 & 15 \\
\hline $\begin{array}{l}\text { Authoritative } \\
\text { physical signs }\end{array}$ & $0 / 758$ & $0 / 721$ & 120 & 120 & $\% 1$ \\
\hline
\end{tabular}

Results obtained indicate that the average anxiety is different in two patenting styles (tolerant and authoritative). This average is $5 / 22$ for the tolerant style and $8 / 75$ for the authoritative style where this difference is significant. Therefore, the significance level obtained (sig=0/387) illustrates that the significance of the above test is less than \%1. Thus, the hypothesis is rejected and the main hypothesis is supported. In other words, there is a significant difference between the two variables mentioned.

Hypothesis 11: There is a difference between the average parenting style scores (tolerant) on the scale of social dysfunction and average parenting style (authoritative)

Table 11. Indicates the t-test and variance homogeneity for the level of social dysfunction in two parenting styles

\begin{tabular}{|l|l|l|l|l|l|}
\hline Variable & $\begin{array}{l}\text { F variance } \\
\text { homogeneity }\end{array}$ & $\begin{array}{l}\mathrm{F} \\
\text { significance }\end{array}$ & T quantity & $\begin{array}{l}\text { Freedom } \\
\text { degree }\end{array}$ & $\begin{array}{l}\text { T } \\
\text { significance }\end{array}$ \\
\hline $\begin{array}{l}\text { Tolerant } \\
\text { style social } \\
\text { dysfunction }\end{array}$ & $0 / 487$ & $0 / 936$ & $2 / 47$ & 152 & 15 \\
\hline $\begin{array}{l}\text { Authoritative } \\
\text { social } \\
\text { dysfunction }\end{array}$ & $0 / 654$ & $0 / 845$ & $2 / 62$ & 121 & $\% 1$ \\
\hline
\end{tabular}

Results obtained indicate that the average social dysfunction is different in two patenting styles (tolerant and authoritative). This average is 6/77 for the tolerant style and 10/29 for the authoritative style where this difference is significant. Therefore, the significance level obtained ( $\operatorname{sig}=0 / 282)$ 
illustrates that the significance of the above test is less than \%1. Thus, the hypothesis is rejected and the main hypothesis is supported. In other words, there is a significant difference between the two variables mentioned.

Hypothesis 12: There is a difference between the parenting style (tolerant) on the scale of depression with the average [parenting style (permissive)

Table 12. Indicates t-test and homogeneity of variances for the level of depression in the two parenting styles

\begin{tabular}{|l|l|l|l|l|l|}
\hline Variable & $\begin{array}{l}\text { F variance } \\
\text { homogeneity }\end{array}$ & $\begin{array}{l}\mathrm{F} \\
\text { significance }\end{array}$ & T quantity & $\begin{array}{l}\text { Freedom } \\
\text { degree }\end{array}$ & $\begin{array}{l}\text { T } \\
\text { significance }\end{array}$ \\
\hline $\begin{array}{l}\text { Tolerant } \\
\text { style } \\
\text { depression }\end{array}$ & $1 / 404$ & $0 / 186$ & $1 / 77$ & 148 & $\% 5$ \\
\hline $\begin{array}{l}\text { Authoritative } \\
\text { depression }\end{array}$ & $1 / 619$ & $0 / 148$ & $1 / 56$ & 64 & $\% 5$ \\
\hline
\end{tabular}

Results obtained indicate that the average depression is different in two patenting styles (tolerant and permissive). This average is $5 / 55$ for the tolerant style and $8 / 36$ for the permissive style where this difference is significant. Therefore, the significance level obtained illustrates that the significance of the above test is less than $\% 5$. Thus, the hypothesis is rejected and the main hypothesis is supported. In other words, there is a significant difference between the two variables mentioned.

Hypothesis 13: There is a difference between patenting style scores (tolerant) on the scale of anxiety with the average parenting style (permissive)

Table 13. Indicates $T$ test and variance homogeneity for the level of anxiety in two parenting styles

\begin{tabular}{|l|l|l|l|l|l|}
\hline Variable & $\begin{array}{l}\mathrm{F} \text { variance } \\
\text { homogeneity }\end{array}$ & $\begin{array}{l}\mathrm{F} \\
\text { significance }\end{array}$ & T quantity & $\begin{array}{l}\text { Freedom } \\
\text { degree }\end{array}$ & $\begin{array}{l}\mathrm{T} \\
\text { significance }\end{array}$ \\
\hline $\begin{array}{l}\text { Tolerant } \\
\text { style anxiety }\end{array}$ & $1 / 800$ & $\% 59$ & $2 / 14$ & 152 & $\% 1$ \\
\hline $\begin{array}{l}\text { Permissive } \\
\text { style anxiety }\end{array}$ & $1 / 302$ & $0 / 253$ & $1 / 69$ & 63 & $\% 1$ \\
\hline
\end{tabular}

Results obtained indicate that the average anxiety is different in two patenting styles (tolerant and permissive). This average is $6 / 82$ for the tolerant style and 10/32 for the permissive style where this difference is significant. Therefore, the significance level obtained illustrates that the significance of the above test is less than $\% 1$. Thus, the hypothesis is rejected and the main hypothesis is supported. In other words, there is a significant difference between the two variables mentioned.

Hypothesis 14: There is a difference between the average parenting styles scores (tolerant) on the physical scale with average parenting styles (permissive)

Table 14. Indicates homogeneity of variances and $t$ test for the physical problems in two parenting styles

\begin{tabular}{|l|l|l|l|l|l|}
\hline Variable & $\begin{array}{l}\mathrm{F} \text { variance } \\
\text { homogeneity }\end{array}$ & $\begin{array}{l}\mathrm{F} \\
\text { significance }\end{array}$ & T quantity & $\begin{array}{l}\text { Freedom } \\
\text { degree }\end{array}$ & $\begin{array}{l}\mathrm{T} \\
\text { significance }\end{array}$ \\
\hline $\begin{array}{l}\text { Tolerant } \\
\text { style physical } \\
\text { problems }\end{array}$ & $2 / 250$ & $\% 15$ & $0 / 06$ & 152 & $\% 1$ \\
\hline $\begin{array}{l}\text { Permissive } \\
\text { style } \\
\text { physical } \\
\text { problems }\end{array}$ & $1 / 064$ & $0 / 406$ & $1 / 52$ & 62 & $\% 1$ \\
\hline
\end{tabular}


Results obtained indicate that the average physical problem is different in two patenting styles (tolerant and permissive). This average is $5 / 22$ for the tolerant style and $8 / 09$ for the permissive style where this difference is significant. Therefore, the significance level obtained (sig=0/391) illustrates that the significance of the above test is less than \%1. Thus, the hypothesis is rejected and the main hypothesis is supported. In other words, there is a significant difference between the two variables mentioned.

Hypothesis 15: there is a difference between parenting styles scores (tolerant) on the scale of social dysfunction with the average parenting style (permissive)

Table 15. Indicates t-test and variance homogeneity for the social dysfunction in two parenting styles

\begin{tabular}{|l|l|l|l|l|l|}
\hline Variable & $\begin{array}{l}\text { F variance } \\
\text { homogeneity }\end{array}$ & F significance & T quantity & $\begin{array}{l}\text { Freedom } \\
\text { degree }\end{array}$ & $\begin{array}{l}\text { T } \\
\text { significance }\end{array}$ \\
\hline $\begin{array}{l}\text { Tolerant style } \\
\text { social } \\
\text { dysfunction }\end{array}$ & $0 / 770$ & $0 / 721$ & $2 / 47$ & 152 & $\% 1$ \\
\hline $\begin{array}{l}\text { Permissive } \\
\text { style social } \\
\text { dysfunction }\end{array}$ & $0 / 978$ & $0 / 468$ & $1 / 85$ & 61 & $\% 1$ \\
\hline
\end{tabular}

Results obtained indicate that the average social dysfunction is different in two patenting styles (tolerant and permissive). This average is $6 / 77$ for the tolerant style and 13/33 for the permissive style where this difference is significant. Therefore, the significance level obtained (sig=0/282) illustrates that the significance of the above test is less than $\% 1$. Thus, the hypothesis is rejected and the main hypothesis is supported. In other words, there is a significant difference between the two variables mentioned.

\section{CONCLUSION}

As Richter et al conducted a study in 1993 describing the context of the relationship between the existing emotional climate in the family and the adaptation behavior in adulthood, the research findings revealed that the emotional atmosphere along with the rejection and punishment method intervenes in creating internal issues and mental health accompanied with emotional-adaptation strategies. Also, social experiences of childhood era will affect the parent-child relation. Also, in another research by Johnser in 1994 titledauthoritative nurturing of the child and concentration and control over the child, he found out that the child's behavior as an extrovert conduct is positively related with the parents' authorities conducts. Heart in a research in 1990 found that mothers with decisive control were having children less accepted by their peers; such children did incline to apply non-intimate and authoritative styles to resolve their conflicts andproblems. These people were having some mental problems. In accordance with the research conducted, it was stated that parents who do not have good control over their own child and feel less responsible for their own children have a permissive style and their children will consequently grow up to be people of less confidence. This will affect their mental health too. Also, parents having rigid and inflexible conducts on their kids (authoritative), though bringing about a controlled environment for their kids, they allow for their rebellion. This will occasionally lead to troubles on the part of the children. 


\section{References}

[1] Ahmadvand, M. A. (2003). Mental health. Tehran: Payame Noor University Publication.

[2] Ahadi, H., \& Mohsen, N. (1993). Psychology of growth. Tehran: Bonyad publishing institute.

[3] Berk, L. (2001). Psychology of growth, From birth to childhood, Tr. Seyed Yahya Mohamadi. Tehran: Arasbaran Publication.

[4] Ghaemi, A. (2003). Child and disorganized family. Tehran: Parents an instructors publishing co.

[5] Houman, A. (2003). Standardization of mental health questionnaire among Tarbyat Moalem Students. 